Innovative Applications of O.R.

\title{
Trends in efficiency in response to regulatory reforms: The case of Indian and Pakistani commercial banks
}

\author{
Shabbar Jaffry*, Yaseen Ghulam, Joe Cox \\ University of Portsmouth, Portsmouth Business School, Department of Economics, Richmond Building, Portland Street, Portsmouth PO1 3DE, UK
}

\section{A R T I C L E I N F O}

\section{Article history:}

Received 24 September 2007

Accepted 2 November 2012

Available online $\mathrm{xxxx}$

\section{Keywords:}

Efficiency

Technology

Deregulation

Privatisation

Indian banking

Pakistani banking

\begin{abstract}
A B S T R A C T
This paper attempts to estimate trends in the efficiency levels of Indian and Pakistani commercial banks between 1985 and 2003, a time period which encompasses two phases of significant change to the regulation of the financial sector in both countries. Our efficiency estimates show that, during the initial years of the post reform period, a reduction in efficiency is observed for banks in both countries. However, efficiency levels were found to have increased subsequently, suggesting a period of initial adjustment throughout much of the 1990s followed by a subsequent correction in the latter part of the sample period.
\end{abstract}

(c) 2012 Elsevier B.V. All rights reserved.
"One of the major objectives of banking sector reforms has been to enhance efficiency and productivity through competition."

Address by Dr. Y.V. Reddy, Governor, Reserve Bank of India, at the Institute of Bankers of Pakistan, Karachi, on May 18, 2005.

"Far reaching reforms have resulted in a more efficient and competitive financial system."

A Joint IMF-World Bank Mission report on banking reforms in Pakistan.

\section{Introduction}

The measurement of efficiency has become increasingly popular topic in the economics literature. A significant body of work has developed that seeks to estimate the rate at which particular firms are able to produce a given quantity of output conditional upon a quantity of inputs relative to other firms in the same industry and during the same time period. Some of the more prominent examples of industries that have been subjected to such scrutiny would be the banking sectors of a range of economies around the world. Due to data availability, a majority of such effort has been concentrated on banks operating in developed nations. However, in recent years, studies on efficiency in developing countries banking sectors have also started to appear in publication in significant

\footnotetext{
* Corresponding author. Tel.: +44 239284 4125; fax: +44 2392844037.

E-mail address: shabbar.jaffry@port.ac.uk (S. Jaffry).
}

volumes, the result of which being of great interest due to the pivotal role that the banking sector can play in the evolution of a developing economy. The contribution of this paper to this emergent body of literature is to more formally investigate temporal patterns in efficiency levels observed within the banking sectors of India and Pakistan following an extensive program of legal and regulatory reform enacted within the Indian Sub-Continent during the 1990s. We use bootstrapped data envelopment analysis and a subsequent second stage regression in order to make a comparison of temporal patterns in efficiency levels between India and Pakistan. Such a comparison of banks from both countries in this regard is important, as we are analysing two countries that have experienced similar trends in economic performance where both enacted programmes of major reform to their respective financial sectors at around the same time (Howcroft and Ataullah, 2006). It is therefore critical to observe whether banks in both countries responded in the same way to these changes, or if there was a heterogeneous response across countries to the reforms. Contrary to a significant number of other cross country studies of efficiency following a period of reform, Pakistan and India share a host of commonalities such as stage of development, language, culture, and banking structure. Hence, a comparison of efficiency across years and countries is less likely to suffer from problems relating to country heterogeneity. The paper is structured as follows: Section 2 presents an overview of the Indian and Pakistani banking industries, while a summary of efficiency and productivity studies is discussed in Section 3. Section 4 provides conceptual framework and methodology while Section 5 explains the data and Section 6 discusses empirical results followed by a summary and conclusion. 
Table 1

Timeline of Major Financial Reforms in India and Pakistan.

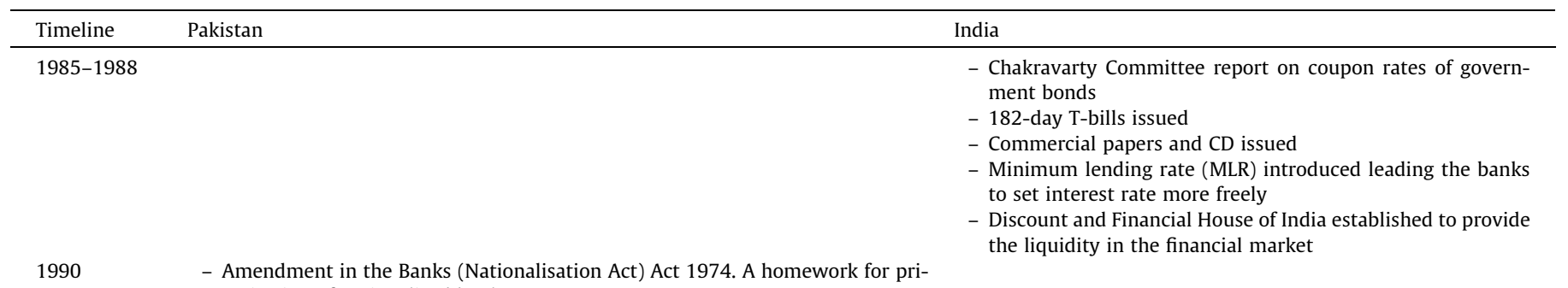

vatisation of nationalised banks

- Setting up Credit Information Bureau within the SBP for data collection of borrowers to be used in creditworthiness by banks

1991 - Privatisation of two state owned public sector banks

- Licence given for opening up of 10 private domestic and three foreign banks

- Creation of National Credit Commission (NCC) to review the flow of credit allocation

1992 - Restructuring of SBP banking supervision department and given more power to monitor the performance of banks

- SBP issued prudential regulation framework

- SBP given power to devise strategies to recover bad loans
- SBP granted autonomy through changes in legislation

- SBP made mandatory for all non-banking financial institutions (NBFIs) to be rated by an independent company approved by the bank

- SBP put moratorium on new banks licensing

\author{
- Narasimham Committee report on banking condition in \\ India with recommendation \\ - MLR increased to $19 \%$ in 1992 \\ - Banks given autonomy to rationalise branches network \\ - RBI recapitalised the public sector banks by injecting INRs 40 \\ billion \\ - MLR lowered to $17 \%$ \\ - Issuing of guideline to establish new private sector banks \\ - RBI issued guideline on income recognition, assets classifica- \\ tion and provisioning \\ - Amendment in State Bank of India Act of 1955 to promote \\ partial private shareholding in banking \\ - MLR lowered \\ - Passing of legislation to recover bad debt \\ - Banks allowed to set fix term deposits freely of a maturity of \\ over two years \\ - New private banks allowed to open rural branches \\ - Guideline issued to set up new Local Area Banks (LABs) in \\ private sector \\ - Banks given power to open/close branches \\ - Banks given instruction to follow minimum capital require- \\ ment for foreign exchange exposure \\ - Reduction in SLR \\ - Introduction of flexible term deposit rates
}

- Commercial banks given power to offer investment-banking service through separate subsidiary

- Pakistan banking council (a regulatory authority) dissolved

- SBP issued instruction to commercial banks in the country to follow International Accounting Standard (IAS) in presentation of their annual accounts

- SBP asked to comply the Risk Weighted Capital standard set by Basle committee and minimum capital raised, which brought a wave of mergers in subsequent years

- SBP recapitalised two public sector banks (PKRs 21 billion in UBL and 9.7 billion in $\mathrm{HBL}$ )

- Autonomy given to public sector banks with respect to branch expansion, recruitment of new staff and new capital expenditure

- RBI deregulated the deposit market more by removing its rates linkage with bank rate

- RBI advised banks to disclose the details of the maturity profile of deposits, borrowing, loans, investment and provisioning

- Public sector banks given powers to rationalise branches and reduce manpowe

- SBP extended the mandatory rating to all commercial banks operating in the country

- Increase in minimum capital requirements

- Establishment of Corporate and Industrial Restructuring Corporation (CIRC) to revive sick industrial units and to take over non-performing loans of commercial banks

- Foreign banks allowed opening up to 25 branches in the country and this limit has been raised to 50 in 2004
- Implementation of CAMEL framework for performance evaluation

\section{Indian and Pakistani banking industries - an overview}

Until the mid-1960s, the banking industries of India and Pakistan enjoyed an environment that was more conducive to competition. Entry and exit was relatively free and banks were able to set their own interest rates without any significant interference by the government or state regulators. However, the second half of the 1960 s and the first half of the 1970s ushered a reversal of such policy, where commercial banks in both countries were nationalised as a part of a move towards broader public ownership. Strict controls on the opening and closing of branches in both countries had contributed to a situation where a large number of public sector banks continued to operate with branches that were not economically viable and were concentrated in areas with large political rents and less competition from the rival banks. However, in the last few years, there have seen significant changes in the way banks are managed and regulated in both countries. In India, the first significant 'wave' of reform began in 1992, under the congress-led government of Narasimha Rao, which was followed by a second 'wave' enacted during the politically unstable era of coalitions in the late 1990s. These changes to the regulation of the Indian banking sector have involved a significant transfer of 
resources away from the public sector and have afforded private sector banks greater levels of autonomy over operational decision making. Table 1 contains a summary of the major reforms enacted in this regard.

In Pakistan, a series of reforms were introduced by the civilian governments of both Benazir Bhutto and Nawaz Sharif (see Table 1 and Ul-Haque and Kardar (1995) and State Bank of Pakistan (2003) for details of these reforms). The major focus of these changes was to promote better use of resources by banks, which should have resultantly brought about improvements in efficiency levels. Table 2 contains the immediate response by the financial sectors of both India and Pakistan to the reforms in terms of the volume of deposits mobilised, profitability and private credits issued, measured in terms of the total assets of the three largest banks over time. The observable trend is that activity in the financial sector has been increasing in both countries following the process of reform, with a higher value of deposits taken and a greater degree of private credit (both relative to GDP) observed from the beginning of the 1990s.

\section{Review of literature}

This paper is by no means the first to focus on a comparison of efficiency in both a pre and post reform period. ${ }^{1}$ There have been a number of studies concerned specifically with the effect of regulatory reform upon the performance of the banking industry in developed economies (see Battese et al. (2000) [Sweden], Heshmati (2001) [Sweden], Canhoto and Dermine (2003) [Portugal], Berger and Humphrey (1997) [International], Baur et al. (1993) [USA], Humphrey (1993), Berger and Mester (1997), and Berger and Mester (2003) [USA], Humphrey and Pulley (1997) [USA], Alam (2001) [USA], Berg et al. (1992) [Norway], Khumbhakar et al. (2001) [Spain] for a selection of examples).

Studies analysing the effect of reforms on developing countries have been somewhat less prevalent: however this is now starting to change. The first comprehensive study to look into the effect of reforms within the Indian banking sector using a DEA methodology is by Bhattacharyya et al. (1997), who analyse the 'early reform period' between 1986 and 1991 and conclude that public sector banks were more efficient compared to private and foreign banks. This is a broad conclusion shared by a number of subsequent studies, including Saha and Ravisankar (2000), Mukherjee et al. (2002), Sathye (2003), and Das and Gosh (2006), as well as a range of unpublished articles or working papers on the Indian and Pakistani banking sectors by authors such as Das et al. (2004), Qayyum and Khan (2007), Burki and Niazi (2003), Ul-Haque (1997), and Saeed and Burki (2005). Other related studies that have used stochastic frontier analysis have demonstrated conclusions that were consistent with those emerging from the DEA based literature (see Iimi (2004), Shanmugam and Das (2004), Patti and Hardy (2005), and Sensarma (2006) for examples). There have also been a limited number of recent studies seeking to make direct comparisons of the response of both India and Pakistan to the reform process. Papers by Howcroft and Ataullah (2006) and Jaffry et al. (2007) broadly agree that the banking sectors of both countries showed improvement in efficiency levels following the reforms.

\section{Methodology}

The last two decades have witnessed an ever-growing volume of literature on post deregulation performance analysis of financial

${ }^{1}$ For a comprehensive review of the literature on the size and scope of liberalisation see (Fanelli and Medhora, 1998). institutions through productivity and efficiency, inspired by the pivotal early work conducted by Aigner et al. (1977) and Meeusen and van den Broeck (1977) on the subject of efficiency. The linear programming based technique of data envelopment analysis (DEA) is a common means by which to estimate the efficiency frontier. ${ }^{2}$ However, Simar and Wilson (2000b) argue that the consistency of the DEA estimator, which is an important property, is compromised when more than one output and input is used and the number of observations must increase to maintain mean-square error with the nonparametric estimators of the constrained efficiency set. Similarly, one must know the sampling distribution of the estimator in order to make inferences about the true level of efficiency/inefficiency. Once known, the asymptotic value of the DEA estimators can be used to correct the bias of the estimator. Asymptotic variance and confidence intervals similarly can be used to form an opinion about the sampling variability of the estimator. Asymptotic properties require a large sample and the curse of dimensionality still applies to the estimator. Simar and Wilson (2000b) argued that a bootstrap (Efron, 1979, 1982) is the next best possible way when inferences are required for the DEA estimator. Since the DEA estimator is biased by its construction, Simar and Wilson (1998) developed an algorithm to approximate the sampling distribution of $\hat{\theta}_{D E A}(x, y)-\theta(x, y)$ where bias is calculated and deducted from estimated efficiencies. Bias in the estimator is approximated as:

$\operatorname{BIAS}\left(\hat{\theta}_{D E A}\left(x_{0}, y_{0}\right)\right)=E\left(\hat{\theta}_{D E A}\left(x_{0}, y_{0}\right)\right)-\theta\left(x_{0}, y_{0}\right)$

As the bootstrap bias estimate for the original estimator $\hat{\theta}_{D E A}\left(x_{0}, y_{0}\right)$ is the empirical analogue of the above, then the bootstrap bias is calculated as:

$\operatorname{BIAS}_{B}\left(\hat{\theta}_{D E A}\left(x_{0}, y_{0}\right)\right)=B^{-1} \sum_{b=1}^{B} \hat{\theta}_{D E A, B}^{*}\left(x_{0}, y_{0}\right)-\hat{\theta}_{D E A}\left(x_{0}, y_{0}\right)$

And the bias corrected estimator of $\theta\left(x_{0}, y_{0}\right)$ is calculated as:

$$
\begin{aligned}
\hat{\hat{\theta}}_{D E A}\left(x_{0}, y_{0}\right) & =\hat{\theta}_{D E A}\left(x_{0}, y_{0}\right)-\operatorname{BIAS}_{B}\left(\hat{\theta}_{D E A}\left(x_{0}, y_{0}\right)\right) \\
& =2 \hat{\theta}_{D E A}\left(x_{0}, y_{0}\right)-B^{-1} \sum_{B=1}^{B} \hat{\theta}_{D E A, b}^{*}\left(x_{0}, y_{0}\right)
\end{aligned}
$$

In this paper, we follow the above mechanism and use the input oriented DEA estimator with its statistical inference developed by Wilson (2008) to test for differences in efficiency across Indian and Pakistani banks over the sample period. Homogeneous bootstrap methodologies are used for this approximation of the asymptotic distribution of distance function estimators where more than one input or output is used to compile the production set, from which the true distance function can be inferred. ${ }^{3}$ In the empirical section of this paper, we report bias-corrected estimates of the input distance function by subtracting potentially noisy estimates of bias from the original distance function estimates. In common with a

\footnotetext{
${ }^{2}$ To calculate DEA efficiency estimates we follow the seminal work of Farrell (1957) as well as the input distance function proposed by Shephard (1970). Refer to these papers for a more detailed explanation of the calculation of efficiency estimates using DEA.

${ }^{3}$ Treating a large number of banking services as outputs creates the curse of dimensionality in a DEA framework, which pushes the efficiency scores upward and, as a consequence, banks producing more and more services are seen to become more efficient. Bootstrapped bias corrected efficiency estimates are robust to the dimensionality issue. Similar to Gilbert et al. (2004) and Simar and Wilson (2000a) we checked the mean square error by calculating the ratio as 1 / times the product of square of the bootstrap bias estimates divided by the sample variance of the bootstrap estimates. If the mean squared error of bootstrapped estimates is worsened, then this ratio should be less than unity and bias corrected estimates should not be used. In our case this ratio is greater than unity (98\% for Pakistani data and $100 \%$ for Indian data). Hence in subsequent analysis we use bias corrected input distance function estimates.
} 
Table 2

Main features of Indian and Pakistani banking industries. Source: Authors compilation from various sources.

\begin{tabular}{|c|c|c|c|c|c|c|c|c|}
\hline & \multicolumn{4}{|l|}{ India } & \multicolumn{4}{|c|}{ Pakistan } \\
\hline & 1985 & 1991 & 1997 & 2003 & 1985 & 1991 & 1997 & 2003 \\
\hline \multicolumn{9}{|l|}{ Market } \\
\hline Number of banks & 79 & 74 & 100 & 93 & 19 & 36 & 46 & 40 \\
\hline Number of branches & 40,574 & 46,396 & 49,641 & 52,392 & 6748 & 7549 & 7039 & 6916 \\
\hline Herfindhal Index (Assets) & 0.09 & 0.08 & 0.05 & 0.05 & 0.26 & 0.25 & 0.23 & 0.20 \\
\hline Share of top three banks (\%) & 40 & 41 & 36 & 35 & 81 & 71 & 53 & 49 \\
\hline Share of public banks & 93 & 88 & 85 & 85 & 93 & 86 & 50 & 38 \\
\hline Banking deposits to GDP & 0.31 & 0.32 & 0.35 & 0.50 & 0.26 & 0.23 & 0.33 & 0.39 \\
\hline Private credits to GDP & 0.30 & 0.23 & 0.22 & 0.31 & 0.25 & 0.22 & 0.24 & 0.27 \\
\hline \multicolumn{9}{|l|}{ Prices } \\
\hline WA lending rate (\%) & 17.1 & 14.0 & 14.6 & 9.9 & 10.49 & 13.3 & 14.55 & 9.40 \\
\hline WA deposits rate (\%) & 10.1 & 7.50 & 7.80 & 6.40 & 5.76 & 6.00 & 6.80 & 2.09 \\
\hline \multicolumn{9}{|l|}{ Profitability } \\
\hline ROA (\%) & 0.1 & 0.4 & 0.7 & 1.0 & 0.1 & 0.5 & -1.2 & 1.40 \\
\hline \multicolumn{9}{|l|}{ Asset auality } \\
\hline NPL as a $\%$ of advances & 20.1 & 23.1 & 15.7 & 8.8 & 18.1 & 19.9 & 23.5 & 17.0 \\
\hline \multicolumn{9}{|l|}{ Liquidity } \\
\hline Loans to deposits (\%) & 67.8 & 60.4 & 55.0 & 56.9 & 52.1 & 54.1 & 55 & 57 \\
\hline \multicolumn{9}{|l|}{ Capitalisation } \\
\hline Equity to assets ratio (\%) & 1.5 & 2.5 & 6.5 & 5.5 & 3.1 & 3.7 & 4.5 & 8.5 \\
\hline
\end{tabular}

number of other studies, we use a range of input/output specifications designed to measure the differences in levels of efficiency across different types of banks for both countries.

To observe the influence of environmental variables on efficiency levels, the standard practice employed in the literature has been to regress efficiency estimates on industry and firm-specific variables, as well as variables reflecting the macroeconomic environment of the country. However, due to the potential for serial correlation among estimated efficiencies, standard methods such as Tobit regressions and panel data estimates may be inappropriate. Simar and Wilson (2007) provide a bootstrap procedure based estimator, which improves the statistical efficiency of the second stage regression. We have followed their approach and also reported other commonly used estimators, such as panel data estimators (pooled, within, GLS (generalised least squares) and Tobit), for comparison. The results from this second stage regression can be found in Section 6.2.

\section{Data}

Our data cover a period of nineteen years for both the Indian and Pakistani banking sectors, which encompasses a significant portion of the pre and post reform period for both countries. To our knowledge, this is unique amongst studies that have been conducted into efficiency changes following regulatory reform in the financial sectors of Indian sub-continent. A systematic procedure is used to rank observations in terms of their similarity and dissimilarity to other observations in the data set, in an attempt to remove the influence of outlying observations from our DEA efficiency estimates (as proposed by Wilson, 1993). The final data set is composed of 73 Indian banks (of which 27 are public, 23 are private and 23 are foreign) and 41 Pakistani banks (of which six are public, 16 are private and 19 are foreign). For the purpose of this study, the bank's output levels are measured by (i) loans (ii) investment in private and government securities (iii) time deposits (iv) savings deposits (v) current deposits and (vi) number of branches. ${ }^{4}$ Although there is a debate in the literature over the

\footnotetext{
${ }^{4}$ All monetary quantities were deflated by using the appropriate GDP deflator for each country.
}

nature of input and output selection in banking, for the purposes of our DEA analysis, deposits are considered to be an output, ${ }^{5}$ with inputs being measured by (i) number of employees, (ii) levels of fixed assets and (iii) capital and reserves. The use of branches as an output is consistent with the approach adopted by the banking literature (see Berger and Humphrey (1997) for a general explanation, or Kumbhakar and Sarkar (2003) who look specifically at India) ${ }^{6}$

Although the selection of inputs appropriate to a typical bank is the subject of less debate in the empirical research literature with regard to efficiency measurement, the process is far from straightforward. Treating equity capital (capital and reserves) and fixed assets as variable inputs is relatively uncommon. Typically, equity and fixed assets are treated as quasi-fixed inputs. We believe that equity and fixed assets measured over a long time period wherein banks in the long run have the choice to alter the combinations in accordance with prevailing market conditions and regulatory compliance should be treated more carefully. In our case studies of Indian and Pakistani banking industries we are using nineteen years of data that almost covers four business cycles (1985-1990, 1991-1996, 19972000 and 2001-2003 as per GDP growth rates and overall economic conditions) and implementation of capital adequacy standards following the Basle accords. Further, significant investment in hightech procedures coupled with the introduction of ATM machines in both Indian and Pakistani banking industries has made these two inputs more of a choice rather than a fixed factor on the part

\footnotetext{
${ }^{5}$ Bhattacharyya et al. (1997) stated that treating deposits as outputs makes intuitive sense in the context of Indian banking, as the main objective of bank management post nationalisation has been deposit mobilisation, due to low saving rates and issues associated with the availability of modes of savings. Further Sensarma (2006) argued that treating deposits as outputs can take into account the quality of the services provided by banks.

${ }^{6}$ Similar to deposits, the use of branches as outputs in the context of the banking sectors of developing economies is somewhat controversial. After deregulation, branch rationalisation was used as an important tool for cost cutting, but in some cases branch expansion has been used to enhance the banking service provisions in rural and semi-urban areas. Further, in case of government owned banks expansion rationalisation of branches has also been used as a tool to seek political rent in developing countries and by not including branches would not include an important output proxy and would be equal to penalising these banks. This was among the number of reasons which led the study by Kumbhakar and Sarkar (2003) to include branches as an output.
} 
Table 3

Descriptive statistics of inputs and outputs.

\begin{tabular}{|c|c|c|c|c|c|c|c|c|c|c|}
\hline & \multicolumn{5}{|l|}{ India } & \multicolumn{5}{|c|}{ Pakistan } \\
\hline & Obs & Mean & Std. dev. & Min & Max & Obs & Mean & Std. dev. & Min & Max \\
\hline Employees $(x 1)$ & 1293 & 12,421 & 26,333 & 12 & 239,649 & 564 & 605 & 1282 & 1 & 8300 \\
\hline Capital (x2) & 1293 & 115 & 197 & 0 & 1929 & 564 & 3 & 7 & 0 & 33 \\
\hline Fixed assets $(x 3)$ & 1293 & 506 & 1025 & 0 & 15,030 & 564 & 2442 & 4384 & 19 & 34,623 \\
\hline Time deposits $(y 1)$ & 1293 & 4900 & 10,310 & 2 & 141,975 & 564 & 14,113 & 27,143 & 5 & 155,275 \\
\hline Saving deposits $(y 2)$ & 1293 & 6071 & 14,296 & 0 & 308,895 & 564 & 17,712 & 34,343 & 7 & 184,848 \\
\hline Current deposits ( $y 3$ ) & 1293 & 5711 & 10,927 & 1 & 170,029 & 564 & 9597 & 20,312 & 3 & 120,544 \\
\hline Loans $(y 4)$ & 1293 & 2024 & 4360 & 0 & 71,708 & 564 & 25,139 & 47,031 & 21 & 246,000 \\
\hline Investment ( $y 5$ ) & 1293 & 1412 & 3419 & 0 & 45,307 & 564 & 15,233 & 30,208 & 0 & 179,000 \\
\hline Branches $(y 6)$ & 1293 & 655 & 1131 & 1 & 9071 & 564 & 233 & 515 & 1 & 1993 \\
\hline
\end{tabular}

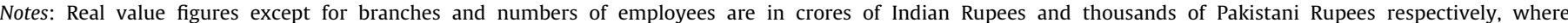

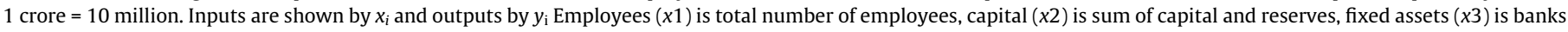

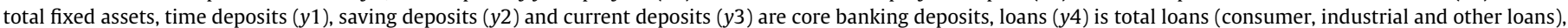

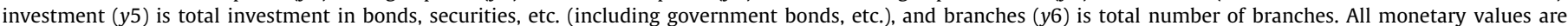
deflated by GDP deflator.

of each bank. In our empirical analysis, we experimented by dropping this assumption: resultantly our broad conclusions remained same in the case of fixed assets but different for equity capital. Descriptive statistics for the input and output variables for both Indian and Pakistani banks can be seen below in Table 3 .

DEA efficiency scores are very sensitive to the choice of inputs and outputs and, as such, we have employed a variety of different specifications of inputs and outputs to test for consistency. Gilbert et al. (2004) explain that one can treat variables as outputs after the point where the addition of a new input variable is unable to reduce estimated levels of inefficiency: hence the final model chosen for subsequent analysis is where inefficiency is minimised for the banks included in the sample.

\section{Estimation and explanation}

The variable returns to scale ${ }^{7}$ input distance function estimates are provided in Appendix A for each bank in the final year of the sample period (2003). The third column in this table (labelled 'Eff') provides original efficiency estimates based on input distance function, while the column labelled ' $\mathrm{Effc}_{\mathrm{c}}$ ' provides the results from the bias corrected input distance function estimates. The final four columns contain estimated upper and lower bounds confidence intervals at $5 \%\left(a_{0.05}, b_{0.05}\right)$ and $1 \%\left(a_{0.01}, b_{0.01}\right)$ significance levels respectively. These estimates, along with the corresponding standard deviations (sigma) imply a reasonable degree of a variation between the most and least efficient banks, especially in Pakistan. The data presented in this table implies that the least efficient Indian bank could have reduced the quantity of inputs employed to generate a given level of output by $39.06 \%^{8}$ whereas the most efficient could feasibly have reduced input quantities by $3.10 \%$ in the final year of the sample. For Pakistan, these numbers indicate a potential reduction in quantity of inputs used equal to $58.37 \%$ and $12.05 \%$ respectively. These estimates are broadly in line with other studies that have estimated efficiency scores for Indian and Pakistani banks.

When banks are differentiated according to their ownership, further insights are made possible. For Indian banks, the average potential input reductions in the final year of the sample period (2003) are estimated to be $16.94 \%, 9.91 \%$ and $7.31 \%$ for foreign,

\footnotetext{
${ }^{7}$ Although we present variable returns to scale efficiency estimates here but we also estimated our models with constant and non-increasing returns to scale assumptions. These estimates are available from the authors upon request. The broad conclusions arrived at, however, remain the same.

8 This is calculated as $(1-[1 / n] * 100)$, where $n$ represents the bias corrected input distance function efficiency estimate for any given bank, as seen in the 'effc' column of Appendix A.
}

private and public sector banks respectively. For Pakistan, these figures are $27.11 \%, 26.91 \%$ and $14.38 \%$ for foreign, private and public sector banks. ${ }^{9}$

\subsection{Investigating temporal patterns in efficiency estimates and variance}

The mean input distance function estimates for the entire sample are shown graphically for the final model specification, as well as the four alternate models with different input and output specifications in Fig. 1a and b, below. The trends in input distance estimates remain consistent between specifications - the exclusion/inclusion of different inputs and outputs merely serves to shift the curve vertically.

For India, it is observed that banks operated with some level of inefficiency before the first reforms occurred in 1992. It can also be seen that an upturn in efficiency was experienced from the late 1990s onwards. In the first few years of the reform period, banks invested heavily in infrastructure, such as buildings and technology (including the purchase of both software and hardware) and returns from these investments materialised later. The efficiency decline in the first few years following reform can be explained in part due to the stringent requirements of asset classification, income recognition and provisioning guidelines (Saha and Ravisankar, 2000). Improved performance in the latter years of the sample period is partly due to the above average performance of public sector banks. Bhaumik and Dimova (2004) argued that public sector banks have managed to bridge the difference with private banks in the post reform period - hence the influence of competition seems to be more important compared with ownership per se.

Pakistan's temporal pattern of efficiency change shown in Fig. 1 has been more erratic than that observed in India, although similar general trends can be observed.

\footnotetext{
${ }^{9}$ Sensarma (2006), while discussing the modest performance of Indian foreign banks argued that lack of efficiency arises for a variety of reasons. Foreign banks usually recruit well-paid officers compared to domestic private banks who may opt for more modestly salaried clerical and subordinate staff in their overall workforce. Foreign banks may operate through branch offices rather than full subsidiaries and parent banks may put less effort into making these branch offices more efficient. The fact that these foreign branch offices are not listed on Indian stock exchanges could be considered to create less in the way of pressure from the market to perform well. Bhattacharyya et al. (1997) argued that the better performance of foreign banks in the late 1980s can be partly be explained due to Non Resident Indians (NRIs) using these banks to keep deposits at higher interest rates and send remittances through the network of these global banks with better and more reliable service provision. However, a huge investment by domestic private and public sector banks in technology and customer service may have closed the service quality gap between foreign and domestic banks in the post reform period.
} 

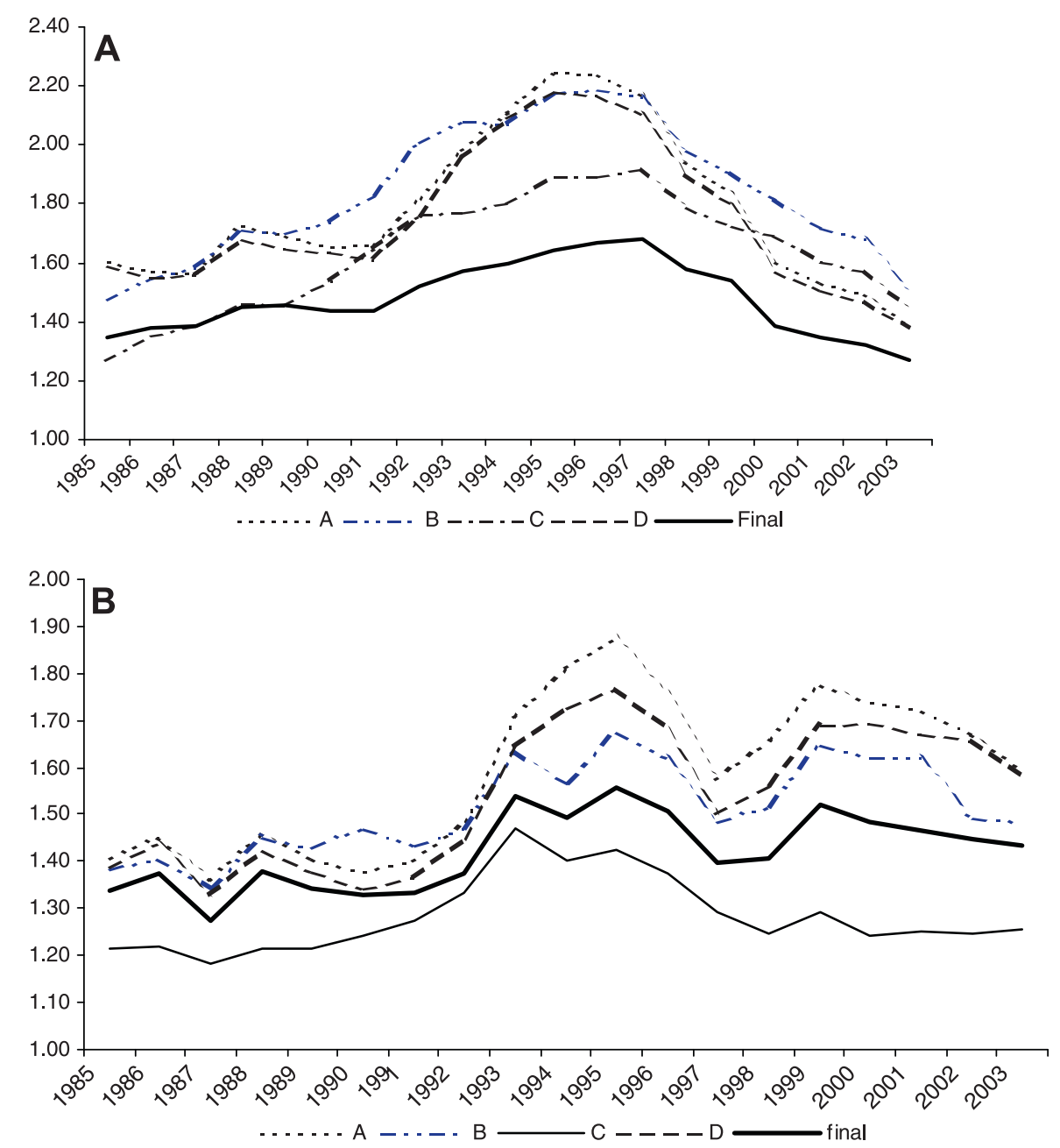

\section{Note: Choice of inputs and outputs and input use efficiency estimates Inputs \\ fixed assets, employees, capital and reserves fixed assets, employees, capital and reserves fixed assets, employees, capital and reserves deposits, loans, investment, branches and income \\ Final: fixed assets, employees, capital and reserves \\ *deposits includes three types: demand, fixed and saving \\ *Lower score in the above figures implies an improvement in input use efficiency}

Fig. 1. (a) Mean efficiency estimates of Indian banks. (b) Mean efficiency estimates of Pakistani banks.

Pakistani banks seem to have displayed decreasing levels of efficiency from the late 1980s up until the mid 1990s, where a very slight reduction in distance from the frontier is subsequently observed during most years of the sample period. A reversal in efficiency declines can be explained as a result of improving economic conditions after 1999 (the only years to demonstrate an exception to this trend are 1997 and 1998, dates corresponding to the Asian financial crisis). The improvement in efficiency observed from the late 1990s is not of the same magnitude as that observed for Indian banks.

Iimi (2003) concluded that, for Pakistani banks after 1999, differentials in efficiency levels increased due to the fact that some banks had opted for extensive internal restructuring compared with other banks. The higher dispersion in efficiency between 1998 and 2002 is consistent with the intuition that the liberalisation of interest rates and credit ceilings combined with considerable macroeconomic volatility gave room for vastly different portfolio choices compared to the cluster of portfolios by Pakistani banks in the pre reform period (Patti and Hardy, 2005). The overall message coming out of these average input distance function estimates is that for both India and Pakistan, in the period immediately following regulatory reform, efficiency levels worsened (which Ataullah et al. (2004) also find), but then subsequently improved during the second reform period. These are conclusions that are also shared by other studies on Indian banks (see, Galagedera and Edirisuriya (2004), Mohan and Ray (2004), Reddy (2005), Zhao et al. (2006), and Mahesh and Rajeeve (2006) for examples).

\subsection{Second stage estimation: factors explaining efficiency estimates}

Table 4 displays the full listing of variables used to construct the second stage regression model, as well as the results. A number of different model specification are used to regress distance function estimates (and hence, inversely, efficiency levels) against a number of explanatory factors listed below. Due to multiple observations for each bank in the sample, robust standard errors are calculated. Further, due to endogeneity of operating expenditure ratio and in the presence of heteroskedasticity and autocorrelation in the 
Table 4

Second stage panel data regression estimates.

\begin{tabular}{|c|c|c|c|c|c|c|c|c|c|c|}
\hline \multirow[t]{2}{*}{ Variables } & \multicolumn{5}{|l|}{ India } & \multicolumn{5}{|l|}{ Pakistan } \\
\hline & Pooled $^{\mathrm{a}}$ & Within ${ }^{\mathrm{b}}$ & $\mathrm{GLS}^{\mathrm{c}}$ & Tobit $^{\mathrm{d}}$ & Simar $^{\mathrm{e}}$ & Pooled $^{\mathrm{a}}$ & Withinb & GLSc & Tobit $^{\mathrm{e}}$ & Simar $^{\mathrm{e}}$ \\
\hline \multicolumn{11}{|c|}{ Internal operational variables } \\
\hline$b$ & -0.02 & -0.002 & $-0.184^{* * *}$ & $-0.625^{* * *}$ & 0.073 & $-0.251^{* *}$ & $-0.499^{* * *}$ & $-0.144^{* * *}$ & $-0.185^{* * *}$ & -0.675 \\
\hline$e$ & $6.617^{* * *}$ & $9.053^{* * *}$ & $7.125^{* * *}$ & $8.258^{* * *}$ & $-1.147^{* *}$ & $7.162^{* * *}$ & $5.044^{* * *}$ & $2.792^{* * *}$ & $5.870^{* * *}$ & $16.821^{* * *}$ \\
\hline$d$ & $1.815^{* * *}$ & $3.540^{* * *}$ & $0.739^{* * *}$ & $2.776^{* * *}$ & 0.581 & 0.06 & -0.019 & -0.125 & -0.159 & 0.264 \\
\hline roa & 0.716 & $1.627^{* *}$ & -0.372 & $1.408^{*}$ & $-3.763^{* * *}$ & 0.368 & -0.016 & -0.122 & 0.06 & $1.092^{* *}$ \\
\hline td & $1.502^{* * *}$ & $1.467^{* * *}$ & $0.444^{* * *}$ & $1.312^{* * *}$ & 0.11 & $-0.645^{* *}$ & -0.122 & $-0.285^{* * *}$ & -0.023 & $-1.883^{* *}$ \\
\hline ia & 0.044 & -0.199 & $-0.238^{* * *}$ & $-0.208^{*}$ & $-0.543^{* * *}$ & -0.457 & $-0.495^{* * *}$ & $-0.333^{* * *}$ & $-0.434^{* *}$ & $-1.334^{* * *}$ \\
\hline ds & $-0.127^{* * *}$ & $-0.587^{* * *}$ & $-0.096^{* * *}$ & $-0.424^{* * *}$ & -0.005 & 0.102 & 0.053 & $0.059^{*}$ & $0.083^{* *}$ & 0.234 \\
\hline oexp & 0.266 & 0.036 & 0.074 & 0.163 & -1.718 & $0.516^{*}$ & $0.560^{* *}$ & 0.111 & $0.540^{* * *}$ & 0.687 \\
\hline$e 2$ & $-9.785^{* *}$ & $-15.482^{* * *}$ & $-15.189^{* * *}$ & $-13.699^{* * *}$ & $-17.003^{* * *}$ & $-12.640^{* *}$ & $-7.820^{* * *}$ & -2.487 & $-9.050^{* * *}$ & $-32.122^{* * *}$ \\
\hline $\mathrm{cd}$ & $1.135^{*}$ & $1.288^{* * *}$ & $0.390^{*}$ & $0.870^{* * *}$ & $0.393^{* * *}$ & $-0.516 b^{*}$ & $-0.364^{* *}$ & -0.081 & $-0.248^{*}$ & $-1.478^{* * *}$ \\
\hline \multicolumn{11}{|c|}{ Macroeconomic variables } \\
\hline gdp & $0.013^{* *}$ & $0.011^{*}$ & 0.001 & $0.012^{*}$ & -0.04 & 0.013 & 0.006 & $0.010^{* *}$ & 0.008 & 0.018 \\
\hline inf & 0.004 & $0.008^{*}$ & $0.004^{* *}$ & $0.008^{*}$ & -0.009 & -0.012 & -0.006 & -0.005 & -0.007 & -0.044 \\
\hline \multicolumn{11}{|c|}{ Variables reflecting competitive environment } \\
\hline$h$ & 2.564 & 4.2 & $2.944^{*}$ & 3.563 & 5.457 & $5.615^{*}$ & 3.606 & -0.947 & $5.726^{*}$ & -4.804 \\
\hline$h 2$ & -12.059 & -27.367 & -19.444 & -21.036 & $-23.627^{* * *}$ & -9.022 & -6.218 & 2.322 & $-10.526^{*}$ & $16.503^{* * *}$ \\
\hline \multicolumn{11}{|c|}{ Time dummies } \\
\hline d9397 & -0.02 & 0.045 & 0.011 & 0.031 & 0.177 & $0.263^{* *}$ & $0.171^{*}$ & $0.071^{*}$ & $0.193^{*}$ & 0.244 \\
\hline d9803 & -0.118 & 0.003 & $-0.057^{* *}$ & -0.031 & 0.024 & 0.192 & 0.153 & -0.026 & 0.159 & $-0.294^{* *}$ \\
\hline \multicolumn{11}{|c|}{ Supplementary information } \\
\hline Constant & $-1.597^{*}$ & 0.174 & $0.645^{* * *}$ & 0.031 & & -0.108 & $0.904^{*}$ & $1.189^{* * *}$ & 0.136 & \\
\hline$N$ & 1293 & 1293 & 1293 & 1293 & 1293 & 564 & 564 & 564 & 564 & 564 \\
\hline
\end{tabular}

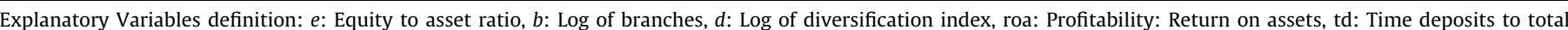

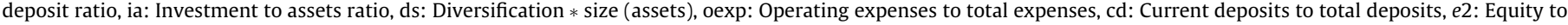
asset ratio (square), gdp: Macroeconomic: GDP growth rate, inf: Macroeconomic: Inflation rate, $h$ : Herfindhal Index.

a Robust standard error estimates, 2 .

b Instrumental within effect estimator (oexp instrumented by call money rate, log of total assets, yearly dummies, td, sd,cd, dummies for public and foreign ownerships. Instruments were selected based on their theoretical relevance and literature).

c Heteroskedastic and autocorrelation consistent iterated feasible generalised least square (FGLS) estimates.

d Random effect tobit estimates (with truncation limit 1 imposed).

e Simar and Wilson (2007) estimator.

${ }^{*} p<0.05$.

** $p<0.01$.

*** $p<0.001$

panel, we used instrumental variable between effect and iterated feasible generalised least square estimator in regard to the effect of different explanatory variables on the biased corrected efficiency estimates.

The results indicate that, for both countries, banks that have increased numbers of branches, investment to assets ratios, squared equity to assets ratios and squared Herfindhal indices display higher levels of efficiency, while higher equity to assets ratios are associated with lower levels of efficiency A negative relationship is observed for diversification, ${ }^{10}$ time deposits to total deposits ratio, current deposits to total deposits ratio and inflation variables of Indian banks, while a positive relationship is observed for Pakistani banks. ${ }^{11}$ The opposite is true with respect to the diversification $*$ size variable, where the coefficient suggests a positive relationship with efficiency in India and a negative relationship in Pakistan. These results indicate that banks which have larger branch networks, have

\footnotetext{
10 We followed Aly et al. (1990) to calculate a measure of product diversity (D) as: $\mathrm{D}=-\ln \sum_{i=1}^{n} \mathrm{Si}^{2}$ where $\ln$ is a natural $\log , \mathrm{S}_{\mathrm{i}}$ is the proportion of a bank's total loans/ deposits accounted by the ith product. Generally, this index is generated by calculating the contribution of different income or sales to the total income of the bank. Due to the nature of the banking system for developing countries, where $90 \%$ of revenue is earned through lending business; we calculated the total business by summing up loans and deposits business and then the calculated share of each ones' contribution. This index can take a very low value for a single product bank and increases in value when more products are offered.

11 Burki and Niazi (2003), in regressing allocative efficiencies in Pakistani banking on a set of variables observed a positive relationship for assets, negative for branches and positive for liquid assets/total assets.
}

higher levels of investments relative to total assets and operating in a more competitive environment will display the highest levels of efficiency, while those that have a greater proportion of equity in their total assets display lower levels. ${ }^{12}$

Also of note would be the time dummies used to represent the first and second waves of reform, which add weight to the argument that the reform process of the early to mid 1990s seems to have had a negative effect on efficiency (particularly in Pakistan), while the second wave of reform from 1998 onwards has had a

\footnotetext{
12 This negative relation between efficiency and capital though not expected, but nonetheless found in earlier studies. Hughes and Mester $(1998,2009)$, Berger and De Young (1997), Kwan and Eisenbeis (1997), Williams (2004), and Altunbas et al. (2007) argued that both capital and risk are likely to be determined by the level of bank efficiency. Contrary to other studies, Altunbas et al. (2007), however, found a negative relationship between efficiency and bank capital. They argued that supervisory authorities are likely to be more flexible in terms of their capital leverage with more efficient banks. On the contrary, a less efficient bank is likely to take on higher risk with low capital to compensate for lost returns due to moral hazard. But this positive relationship between higher capita/asset ratio to efficiency is re-established at a quite higher level of bank capitalisation (e2). The number of branches indicates size and the increase in efficiency due to the large number of branches, which could be an indication of scale economies. Higher investment to asset ratio could be a proxy for management ability to expand the business to non-traditional business. Interestingly, market concentration measured by the Herfindhal index points to a structure conduct performance (i.e. more concentration, less efficient) framework..However, the relationship is not significant across different estimators. Similarly, a non-linear relationship between concentration and efficiency is also not significant across different estimators but nonetheless consistently points to a relative efficiency model at a very high level of concentration.
} 
positive effect. This is consistent with the adjustment/correction results outlined above.

\section{Conclusion}

This paper has attempted to estimate an input distance function for Indian and Pakistani banks over the period between 1985 and 2003 using methodologies described by Simar and Wilson (2000b), Wilson (2008), and Gilbert et al. (2004). The sample period is characterised by significant changes to the regulatory environment in the Indian Sub-Continent, with major changes brought about in 1992 and 1998. It appears that the regulatory changes introduced in 1992 have not initially had a desirable effect on the efficiency of both Indian and Pakistani banks. However, it seems that banks were slowly able to adapt to the new competitive environment in the final years of the 1990s, and continued to make efficiency improvements throughout the early part of the 21st Century. This suggests a period of initial adjustment to the new regulatory environment throughout much of the period immediately following the reforms, followed by a sharp correction towards the end of the sample. In terms of policy implications, our results indicate that it takes time for banks to adjust to reforms to the regulatory environment and that increased competition amongst banks is eventually found to impact positively upon efficiency levels. Patience, therefore, is found to be a virtue in prudential banking regulation.

\section{Acknowledgement}

We are thankful to Abid Burki, Daniel Hardy, Jameel Ahmad, K. R. Shanmugam, Sumon Kumar Bhaumik, Subrata Sarkar, and Subal Kumbhakar for their help in compiling the data for this study.

\section{Appendix A}

A.1. Input distance function estimates (2003)

\begin{tabular}{|c|c|c|c|c|c|c|c|c|c|}
\hline Bank & Type & Eff & Effc & Bias & Sigma & $a_{0.05}$ & $b_{0.05}$ & $a_{0.01}$ & $b_{0.01}$ \\
\hline \multicolumn{10}{|l|}{ India } \\
\hline 1 & Public & 1.859 & 1.068 & -0.068 & 0.007 & 1.002 & 1.335 & 1.000 & 1.370 \\
\hline 2 & Public & 1.859 & 1.060 & -0.060 & 0.004 & 1.001 & 1.220 & 1.000 & 1.308 \\
\hline 3 & Public & 1.043 & 1.075 & -0.032 & 0.001 & 1.044 & 1.155 & 1.043 & 1.257 \\
\hline 4 & Public & 1.859 & 1.056 & -0.056 & 0.003 & 1.002 & 1.198 & 1.000 & 1.220 \\
\hline 5 & Public & 1.859 & 1.042 & -0.042 & 0.001 & 1.002 & 1.140 & 1.001 & 1.173 \\
\hline 6 & Public & 1.093 & 1.125 & -0.032 & 0.001 & 1.095 & 1.214 & 1.093 & 1.304 \\
\hline 7 & Public & 1.859 & 1.065 & -0.065 & 0.005 & 1.001 & 1.242 & 1.000 & 1.298 \\
\hline 8 & Public & 1.007 & 1.032 & -0.025 & 0.000 & 1.009 & 1.073 & 1.008 & 1.086 \\
\hline 9 & Public & 1.859 & 1.048 & -0.048 & 0.002 & 1.001 & 1.149 & 1.000 & 1.215 \\
\hline 10 & Public & 1.859 & 1.064 & -0.064 & 0.005 & 1.002 & 1.259 & 1.000 & 1.323 \\
\hline 11 & Public & 1.859 & 1.048 & -0.048 & 0.002 & 1.001 & 1.163 & 1.000 & 1.230 \\
\hline 12 & Public & 1.859 & 1.057 & -0.057 & 0.003 & 1.002 & 1.191 & 1.000 & 1.270 \\
\hline 13 & Public & 1.859 & 1.070 & -0.070 & 0.008 & 1.001 & 1.334 & 1.000 & 1.372 \\
\hline 14 & Public & 1.859 & 1.051 & -0.051 & 0.002 & 1.001 & 1.154 & 1.000 & 1.177 \\
\hline 15 & Public & 1.402 & 1.442 & -0.040 & 0.001 & 1.404 & 1.520 & 1.403 & 1.601 \\
\hline 16 & Public & 1.048 & 1.074 & -0.027 & 0.000 & 1.050 & 1.109 & 1.048 & 1.124 \\
\hline 17 & Public & 1.002 & 1.032 & -0.030 & 0.001 & 1.004 & 1.098 & 1.002 & 1.138 \\
\hline 18 & Public & 1.859 & 1.065 & -0.065 & 0.006 & 1.001 & 1.288 & 1.000 & 1.320 \\
\hline 19 & Public & 1.859 & 1.063 & -0.063 & 0.005 & 1.002 & 1.238 & 1.000 & 1.275 \\
\hline 20 & Public & 1.859 & 1.032 & -0.032 & 0.001 & 1.002 & 1.092 & 1.000 & 1.134 \\
\hline 21 & Public & 1.859 & 1.069 & -0.069 & 0.008 & 1.001 & 1.335 & 1.000 & 1.368 \\
\hline 22 & Public & 1.119 & 1.154 & -0.036 & 0.001 & 1.120 & 1.231 & 1.118 & 1.253 \\
\hline 23 & Public & 1.076 & 1.104 & -0.029 & 0.000 & 1.077 & 1.142 & 1.075 & 1.157 \\
\hline 24 & Public & 1.859 & 1.051 & -0.051 & 0.002 & 1.001 & 1.162 & 1.000 & 1.187 \\
\hline 25 & Public & 1.859 & 1.061 & -0.061 & 0.004 & 1.002 & 1.211 & 1.000 & 1.230 \\
\hline 26 & Public & 1.019 & 1.049 & -0.030 & 0.000 & 1.021 & 1.102 & 1.020 & 1.134 \\
\hline 27 & Public & 1.859 & 1.071 & -0.071 & 0.008 & 1.002 & 1.330 & 1.000 & 1.375 \\
\hline 28 & Private & 1.859 & 1.053 & -0.053 & 0.003 & 1.002 & 1.184 & 1.000 & 1.228 \\
\hline 29 & Private & 1.859 & 1.068 & -0.068 & 0.007 & 1.001 & 1.287 & 1.000 & 1.319 \\
\hline 30 & Private & 1.859 & 1.036 & -0.036 & 0.001 & 1.002 & 1.099 & 1.000 & 1.127 \\
\hline 31 & Private & 1.859 & 1.063 & -0.063 & 0.005 & 1.002 & 1.226 & 1.000 & 1.243 \\
\hline 32 & Private & 1.859 & 1.064 & -0.064 & 0.005 & 1.002 & 1.232 & 1.000 & 1.255 \\
\hline 33 & Private & 1.859 & 1.060 & -0.060 & 0.004 & 1.002 & 1.218 & 1.000 & 1.245 \\
\hline 34 & Private & 1.333 & 1.375 & -0.042 & 0.001 & 1.335 & 1.488 & 1.333 & 1.528 \\
\hline 35 & Private & 1.090 & 1.123 & -0.032 & 0.001 & 1.092 & 1.223 & 1.090 & 1.261 \\
\hline 37 & Private & 1.859 & 1.053 & -0.053 & 0.003 & 1.002 & 1.182 & 1.000 & 1.252 \\
\hline 38 & Private & 1.289 & 1.323 & -0.034 & 0.000 & 1.291 & 1.373 & 1.289 & 1.397 \\
\hline 39 & Private & 1.859 & 1.057 & -0.057 & 0.003 & 1.002 & 1.178 & 1.000 & 1.189 \\
\hline 40 & Private & 1.859 & 1.060 & -0.060 & 0.005 & 1.001 & 1.233 & 1.000 & 1.253 \\
\hline 41 & Private & 1.091 & 1.123 & -0.032 & 0.000 & 1.093 & 1.169 & 1.092 & 1.189 \\
\hline
\end{tabular}


(continued)

\begin{tabular}{|c|c|c|c|c|c|c|c|c|c|}
\hline Bank & Type & Eff & Effc & Bias & Sigma & $a_{0.05}$ & $b_{0.05}$ & $a_{0.01}$ & $b_{0.01}$ \\
\hline 42 & Private & 1.859 & 1.054 & -0.054 & 0.003 & 1.002 & 1.180 & 1.000 & 1.196 \\
\hline 43 & Private & 1.114 & 1.149 & -0.035 & 0.001 & 1.117 & 1.203 & 1.115 & 1.225 \\
\hline 46 & Private & 1.185 & 1.219 & -0.033 & 0.001 & 1.187 & 1.293 & 1.186 & 1.317 \\
\hline 48 & Private & 1.859 & 1.059 & -0.059 & 0.004 & 1.002 & 1.218 & 1.000 & 1.314 \\
\hline 49 & Private & 1.859 & 1.046 & -0.046 & 0.002 & 1.001 & 1.153 & 1.000 & 1.213 \\
\hline 51 & Foreign & 1.859 & 1.069 & -0.069 & 0.008 & 1.002 & 1.340 & 1.000 & 1.374 \\
\hline 53 & Foreign & 1.859 & 1.073 & -0.073 & 0.008 & 1.002 & 1.339 & 1.000 & 1.367 \\
\hline 54 & Foreign & 1.336 & 1.375 & -0.039 & 0.001 & 1.338 & 1.448 & 1.336 & 1.496 \\
\hline 55 & Foreign & 1.859 & 1.068 & -0.068 & 0.008 & 1.001 & 1.334 & 1.000 & 1.373 \\
\hline 56 & Foreign & 1.859 & 1.046 & -0.046 & 0.002 & 1.002 & 1.142 & 1.000 & 1.238 \\
\hline 57 & Foreign & 1.098 & 1.134 & -0.036 & 0.001 & 1.100 & 1.209 & 1.099 & 1.263 \\
\hline 58 & Foreign & 1.859 & 1.069 & -0.069 & 0.008 & 1.002 & 1.321 & 1.000 & 1.362 \\
\hline 60 & Foreign & 1.413 & 1.458 & -0.046 & 0.002 & 1.414 & 1.578 & 1.412 & 1.662 \\
\hline 62 & Foreign & 1.589 & 1.641 & -0.052 & 0.003 & 1.591 & 1.774 & 1.589 & 1.958 \\
\hline 63 & Foreign & 1.859 & 1.070 & -0.070 & 0.008 & 1.001 & 1.341 & 1.000 & 1.374 \\
\hline 64 & Foreign & 1.525 & 1.576 & -0.051 & 0.002 & 1.527 & 1.741 & 1.525 & 1.798 \\
\hline 65 & Foreign & 1.859 & 1.067 & -0.067 & 0.007 & 1.002 & 1.322 & 1.000 & 1.370 \\
\hline 67 & Foreign & 1.859 & 1.070 & -0.070 & 0.008 & 1.001 & 1.339 & 1.000 & 1.375 \\
\hline 68 & Foreign & 1.399 & 1.441 & -0.051 & 0.002 & 1.393 & 1.551 & 1.390 & 1.606 \\
\hline 69 & Foreign & 1.140 & 1.176 & -0.036 & 0.001 & 1.142 & 1.283 & 1.141 & 1.396 \\
\hline 70 & Foreign & 1.859 & 1.071 & -0.071 & 0.008 & 1.001 & 1.338 & 1.000 & 1.376 \\
\hline 73 & Foreign & 1.859 & 1.072 & -0.072 & 0.008 & 1.002 & 1.343 & 1.000 & 1.374 \\
\hline \multicolumn{10}{|c|}{ Pakistan } \\
\hline 1 & Foreign & 1.205 & 1.320 & -0.116 & 0.006 & 1.210 & 1.523 & 1.206 & 1.614 \\
\hline 2 & Foreign & 1.859 & 1.167 & -0.167 & 0.016 & 1.007 & 1.415 & 1.001 & 1.468 \\
\hline 3 & Private & 1.859 & 1.167 & -0.167 & 0.020 & 1.005 & 1.494 & 1.002 & 1.550 \\
\hline 4 & Foreign & 2.169 & 2.402 & -0.233 & 0.024 & 2.184 & 2.804 & 2.171 & 2.939 \\
\hline 6 & Private & 1.859 & 1.168 & -0.168 & 0.020 & 1.006 & 1.507 & 1.002 & 1.555 \\
\hline 7 & Private & 1.859 & 1.158 & -0.158 & 0.013 & 1.006 & 1.377 & 1.001 & 1.425 \\
\hline 8 & Private & 1.859 & 1.172 & -0.172 & 0.020 & 1.005 & 1.502 & 1.001 & 1.548 \\
\hline 9 & Foreign & 1.284 & 1.412 & -0.128 & 0.007 & 1.292 & 1.605 & 1.285 & 1.691 \\
\hline 11 & Private & 1.859 & 1.145 & -0.145 & 0.010 & 1.007 & 1.353 & 1.002 & 1.395 \\
\hline 13 & Private & 1.859 & 1.171 & -0.171 & 0.020 & 1.006 & 1.501 & 1.001 & 1.539 \\
\hline 14 & Foreign & 1.859 & 1.170 & -0.170 & 0.020 & 1.006 & 1.508 & 1.002 & 1.555 \\
\hline 15 & Private & 1.886 & 2.058 & -0.172 & 0.012 & 1.899 & 2.342 & 1.887 & 2.430 \\
\hline 17 & Foreign & 1.859 & 1.177 & -0.177 & 0.020 & 1.008 & 1.475 & 1.002 & 1.528 \\
\hline 18 & Foreign & 1.451 & 1.600 & -0.149 & 0.011 & 1.460 & 1.855 & 1.453 & 1.972 \\
\hline 21 & Private & 1.761 & 1.923 & -0.162 & 0.012 & 1.775 & 2.201 & 1.763 & 2.314 \\
\hline 22 & Public & 1.859 & 1.164 & -0.164 & 0.019 & 1.006 & 1.483 & 1.002 & 1.515 \\
\hline 23 & Private & 1.859 & 1.168 & -0.168 & 0.020 & 1.006 & 1.506 & 1.001 & 1.549 \\
\hline 24 & Public & 1.859 & 1.172 & -0.172 & 0.021 & 1.007 & 1.503 & 1.001 & 1.551 \\
\hline 25 & Foreign & 1.859 & 1.137 & -0.137 & 0.009 & 1.007 & 1.363 & 1.001 & 1.407 \\
\hline 28 & Private & 1.859 & 1.147 & -0.147 & 0.010 & 1.006 & 1.371 & 1.001 & 1.421 \\
\hline 29 & Private & 1.859 & 1.165 & -0.165 & 0.017 & 1.006 & 1.443 & 1.001 & 1.493 \\
\hline 30 & Public & 1.859 & 1.167 & -0.167 & 0.020 & 1.005 & 1.502 & 1.001 & 1.541 \\
\hline 31 & Private & 1.859 & 1.174 & -0.174 & 0.020 & 1.008 & 1.502 & 1.001 & 1.561 \\
\hline 32 & Private & 1.696 & 1.858 & -0.162 & 0.011 & 1.705 & 2.095 & 1.697 & 2.120 \\
\hline 33 & Private & 1.453 & 1.584 & -0.131 & 0.005 & 1.461 & 1.737 & 1.455 & 1.780 \\
\hline 34 & Private & 1.486 & 1.614 & -0.127 & 0.005 & 1.496 & 1.762 & 1.488 & 1.814 \\
\hline 35 & Foreign & 1.859 & 1.171 & -0.171 & 0.021 & 1.006 & 1.506 & 1.001 & 1.561 \\
\hline 37 & Private & 1.519 & 1.649 & -0.131 & 0.005 & 1.527 & 1.798 & 1.520 & 1.865 \\
\hline 38 & Foreign & 1.859 & 1.171 & -0.171 & 0.020 & 1.006 & 1.504 & 1.001 & 1.550 \\
\hline 40 & Private & 1.859 & 1.141 & -0.141 & 0.009 & 1.007 & 1.309 & 1.001 & 1.331 \\
\hline 41 & Private & 1.859 & 1.165 & -0.165 & 0.015 & 1.008 & 1.421 & 1.001 & 1.446 \\
\hline
\end{tabular}

\section{References}

Aigner, D.J., Lovell, C.A.K., Schmidt, P.J., 1977. Formulation and estimation of stochastic frontier production function models. Journal of Econometrics 6 (1), 21-37.

Alam, S.I.M., 2001. A non-parametric approach for assessing efficiency dynamics of large US banks. Journal of Money, Credit and Banking 33, 121-139.
Altunbas, Y., Carbo, S., Gardener, E.P.M., Molyneux, P., 2007. Examining the relationships between capital, risk and efficiency in European banking. European Financial Management 13, 49-70.

Aly, H., Richard, G., Carl, P., Nanda, R., 1990. Technical, scale, and allocative efficiencies in US banking: an empirical investigation. The Review of Economics and Statistics $72,211-218$. 
Ataullah, A., Cockerill, T., Le, H., 2004. Financial liberalisation and bank efficiency: a comparative analysis of India and Pakistan. Applied Economics 36, 1915-1924.

Battese, G.E., Heshmanti, A., Hjalmarsson, L., 2000. Efficiency of labour use in the Swedish banking industry: a stochastic frontier approach. Empirical Economics 25, 623-640.

Baur, P.W., Berger, A.N., Humphrey, D.B., 1993. Efficiency and efficiency growth in US banking. In: Fried, H.O., Lovell, C.A.K., Schmidt, S.S. (Eds.), The Measurement of Efficient Efficiency: Techniques and Applications. Oxford University Press, New York, pp. 386-413.

Berger, A.N., De Young, R., 1997. Problem loans and cost efficiency in commercial banking. Journal of Banking and Finance 21, 849-870.

Berger, A.N., Humphrey, D.B., 1997. Efficiency of financial institutions: international survey and direction for future research. European Journal of Operational Research 98, 175-212

Berger, A.N., and Mester, L.J., 1997. Efficiency and Efficiency Change in the US Commercial Banking Industry: A Comparison of 1980s and 1990s. Working paper, 97-5, Federal Reserve Bank of Philadelphia.

Berger, A.N., Mester, L.J., 2003. Explaining the dramatic changes in performance of US banks: technological change, deregulation, and dynamic changes in competition. Journal of Financial Intermediation 12, 57-95.

Berg, S.A., Forsund, F., Jansen, E.S., 1992. Malmquist Indices of efficiency growth during the deregulation of Norwegian banking, 1980-1989. Scandinavian Journal of Economics 94, 211-228.

Bhattacharyya, A., Lovell, C.A.K., Sahay, P., 1997. The impact of liberalisation on the efficient efficiency of Indian commercial banks. European Journal of Operational Research 98, 332-345.

Bhaumik, S.K., Dimova, R., 2004. How important is ownership in a market with level playing field? The Indian banking sector revised. Journal of Comparative Economics 32, 165-180.

Burki, A.A., Niazi, G.S.K., 2003. The effect of privatisation, competition and regulation on banking efficiency in Pakistan, 1991-2000. Paper presented at CRC conference on Regulatory Impact Assessment: Strengthening Regulation Policy and Practice, Chancellors Conference Centre, University of Manchester, Manchester, UK, 26-27 November.

Canhoto, A., Dermine, J., 2003. A note on banking efficiency in Portugal, new vs old banks. Journal of Banking and Finance 27, 2087-2098.

Das, A., Gosh, S., 2006. Financial deregulation and efficiency: an empirical analysis of Indian banks during the post reform period. Review of Financial Economics 15 (3), 193-221.

Das, A., Nag, A., and Ray, S., 2004. Liberalisation, ownership, and efficiency in Indian banking: a nonparametric approach. University of Connecticut, Department of Economics, Working Paper Series, 29.

Efron, B., 1979. Bootstrap methods: another look at the jackknife. Annals of Statistics 7, 1-16.

Efron, B., 1982. The jackknife, the bootstrap and other resample plans. CBMS-NSF Regional Conference Series in Applied Mathematics, vol. 38. SIAM, Philadelphia.

Fanelli, J.M., Medhora, A., 1998. Financial Reforms in Developing Countries. MacMillan Press, London.

Farrell, M.J., 1957. The measurement of efficient efficiency. Journal of the Royal Statistical Society $120,253-281$

Galagedera, D.U.A., Edirisuriya, P., 2004. Performance of Indian Commercial Banks (1995-2002): An Application of Data Envelopment Analysis and Malmquist Efficiency Index. Working Paper Series, Monash University, Department of Econometrics and Business Statistics, Australia.

Gilbert, R.A., Wheelock, D.C., Wilson, P.W., 2004. New evidence on the Fed's efficiency in providing payment services. Journal of Banking and Finance 28, 2175-2190.

Heshmati, A., 2001. Labour demand and efficiency in Swedish savings banks. Applied Financial Economics 11, 423-433.

Howcroft, B., Ataullah, A., 2006. Total factor efficiency change: an examination of the commercial banking industry in India and Pakistan. The Service Industries Journal 26 (2), 189-202.

Hughes, J.P., Mester, L.J., 1998. Bank capitalization and cost: evidence of scale economies in risk management and signalling. The Review of Economics and Statistics 80, 314-325.

Hughes, J.P., Mester, L.J., 2009. Efficiency in banking: theory, practice and evidence. In: Berger, A.N., Molyneux, P., Wilson, J.O.S. (Eds.), Oxford Handbook of Banking. Oxford University Press (chapter 18).

Humphrey, D.B., 1993. Cost and technical change: effects from bank deregulation. Journal of Efficiency Analysis 4, 293-315.

Humphrey, D.B., Pulley, LB., 1997. Bank's response to deregulation: profits, technology and efficiency. Journal of Money, Credit, and Banking 29 (1), 7393.

Iimi, A., 2003. Efficiency in the Pakistani banking industry: empirical evidence after the structural reform in late 1990s. The Pakistan Development Review 42 (1), 41-57.
Iimi, A., 2004. Banking sector reforms in Pakistan: economies of scale and scope, and cost complementarities. Journal of Asian Economics 15, 507-528.

Jaffry, S., Yassen, G., Pascoe, S., Cox, J., 2007. Regulatory changes and efficiency of the banking sector in the Indian sub-continent. Journal of Asian Economics 18, 415438.

Khumbhakar, S.C., Lozano-Vivas, A., Knox-Lovell, C.A., Hasan, I., 2001. The effects of deregulation on the performance of financial institutions: the case of Spanish savings banks. Journal of Money, Credit and Banking 33 (1), 101120.

Kumbhakar, S.C., Sarkar, S., 2003. Deregulation, ownership and efficiency growth in the banking industry: evidence from India. Journal of Money, Credit and Banking 35 (3), 403-424.

Kwan, S., Eisenbeis, R., 1997. Bank risk, capitalization and operating efficiency. Journal of Financial Services Research 12, 117-131.

Mahesh, H.P., Rajeeve, M., 2006. Liberalisation and Efficient Efficiency of Indian Commercial Banks: A Stochastic Frontier Analysis. MPRA Paper, Munich, Germany.

Meeusen, W., van den Broeck, J., 1977. Efficiency estimation from Cobb-Douglas production functions with composed error. International Economic Review 18 (2), 435-444.

Mohan, T.T.R., Ray, S., 2004. Efficiency Growth and Efficiency in Indian Banking: A Comparison of Public, Private and Foreign Banks. University of Connecticut, Department of Economics, Working Paper Series, 27.

Mukherjee, A., Nath, P., Pal, M.N., 2002. Performance benchmarking and strategic homogeneity of Indian banks. International Journal of Bank Marketing 20/3 122-139.

Patti, B.E., Hardy, D.C., 2005. Financial sector liberalization, bank privatization, and efficiency: evidence from Pakistan. Journal of Banking and Finance 29 (8-9) 2381-2406.

Qayyum, A., Khan, S., 2007. X-efficiency, Economy of Scale, Technological Progress and Competition of Pakistanis Banks. Paper presented at Pakistan Society of Development Economic conference, Pakistan Institute of Development Economics, Islamabad, Pakistan.

Reddy, A., 2005. Banking sector deregulation and efficiency change decomposition of Indian banks. Finance India 19, 3, 983-100.

Saeed, A., Burki, A.A., 2005. Financial Sector Reforms and Efficiency Growth in Pakistan's Commercial Banking Sector in the 1990s. Working paper, Lahore University of Management Sciences, Lahore, Pakistan.

Saha, A., Ravisankar, T.S., 2000. Rating of Indian commercial banks: a DEA approach European Journal of Operational Research 124, 187-203.

Sathye, M., 2003. Efficiency of banks in a developing economy: the case of India. European Journal of Operational Research 148, 662-671.

Sensarma, R., 2006. Are foreign banks always the best? Comparison of state-owned private and foreign banks in India. Economic Modelling 23, 717-735.

Shanmugam, K.R., Das, A., 2004. Efficiency of Indian commercial banks during the reform period. Applied Financial Economics 14 (9), 681-686.

Shephard, R.W., 1970. Theory of Cost and Production Function. Princeton University Press, Princeton.

Simar, L., Wilson, P.W., 1998. Sensitivity analysis of efficiency scores: how to bootstrap in nonparametric frontier models. Management Science 44 (11), 4961.

Simar, L., Wilson, P.W., 2000a. A general methodology for bootstrapping in nonparametric frontier models. Journal of Applied Statistics 27, 779802.

Simar, L., Wilson, P.W., 2000b. Statistical inference in nonparametric frontier models: the state of the art. Journal of Efficiency Analysis 13, 49-78.

Simar, L., Wilson, P.W., 2007. Estimation and inference in two-stage, semiparametric models of production processes. Journal of Econometrics 136 (1) 31-64.

State Bank of Pakistan, 2003. Financial Sector Assessment 1990-2000. Karachi, Pakistan.

Ul-Haque, N., 1997. Financial market reform in Pakistan. The Pakistan Development Review 36 (4), 839-854 (part II).

Ul-Haque, N., Kardar, S., 1995. Development of the financial sector in Pakistan. In: Zahid, S.N. (Ed.), Financial Sector Development in Asia: Country Studies. Asian Development Banks, Manila, Philippines.

Williams, J., 2004. Determining management behaviour in European banking Journal of Banking and Finance 28, 2427-2460.

Wilson, P.W., 1993. Detecting outliers in deterministic non-parametric frontier models with multiple outputs. Journal of Business and Economic Statistics 11 (3), 319-323.

Wilson, P.W., 2008. FEAR: a package for frontier efficiency analysis with R. SocioEconomic Planning Sciences 42 (4), 247-254.

Zhao T., Casu, B., Ferrari, A., 2006. Deregulation and Efficiency Growth: A Study of Indian Commercial Banking. Discussion paper series, University of Reading, Department of Economics, UK. 